\title{
The Establishment of Self Concept on Early Childhood Through the Interactive Fable Taleat Pertiwi 49 Kindergarten in Gunungpati
}

\author{
Henny Puji Astuti \\ Universitas Negeri Semarang \\ Semarang, Indonesia \\ hennypa@mail.unnes.ac.id
}

\author{
Ni Kadek Aris Rahmadani \\ Universitas Negeri Semarang \\ Semarang, Indonesia \\ kadekaris@mail.unnes.ac.id
}

\author{
R Agustinus Arum Eko Nugroho \\ Universitas Negeri Semarang \\ Semarang, Indonesia \\ agustinus.arum@mail.unnes.ac.id
}

\begin{abstract}
The self-concept of early childhood is the perspective or judgment of early childhood against them in a positive position on social life. Developing children with not confident, so they could not reach are sprouting optimally. Fable will give learning experience for them. Interactive fable tale is a work of art of the story of a beast does not occurring completely or story prose people by involving skill of sports story good and involving communication interactive, where based in interactions reciprocal and cooperation to build a story whole between childhood and storyteller. The hypothesis proposed in this study is that there are differences in self-concept of early childhood in interactive fable tale implementation. The subject of the research is 32 children. Data collection method used scale self-concept positive aud. An analysis of independent sample t-test show results $t=2.661$ with $p<0.05$. Based on the results of the study, it can be concluded that there are significant differences in selfconcept of early childhood viewed from the interactive fable tale. The self-concept of early childhood in the experimental group is higher than the control group.
\end{abstract}

Keywords—self concept; interactive fable tale; early childhood

\section{INTRODUCTION}

Early childhood is considered an individual who just started to know the world. They have not understood manners, manners, rules, norms, ethics, and other things related to the life of the world[1]. Pre-school age is a time for a child to learn communication with others and be able to understand it[2]. Therefore, a child needs to be guided and stimulated to understand things about the life of the world. Their selfpresentation is influenced by their own capital. The more possessions will be comparable to those that can be shown to others.

Giving stimulation in early childhood during the process of personality development is very important[3]. Early childhood is a group of 0-6 years-old children who are in the process of growth and unique development[4]. Stimulation is identical with the provision of stimuli that come from the environment around the children to better optimize children's development aspects. Confidence is also a reflection of the attached object. Children will identify the adults and their surrounding peers. Self-concept is a set of beliefs we have about ourselves and their relationship to behavior in certain situations [5]. The concept of self-concept is a personal view someone has about oneself[6]. The self-concept appraiser is oneself. We cannot know what others think. This self-concept is individual. Therefore, the way to interpret it also depends on the individual person. The factors which influence individual selfconcept are parents, peers, society, and learning[7].

In early observation seen some early childhood Pertiwi 49 Kindergarten in Ngijo, Gunungpati not be able to develop self-concept optimally. Self-concept is the way the individual sees himself. Some of them are children who do not respond when asked, hide behind the teacher's body, shame, and often crying if they cannot complete the task. Some children seem not confident enough and he choose to play with him. Others seem to dislike their playmates and tend to mock each other. Early childhood should have a positive selfconcept, able to join the environment and to develop them. Storytelling is a fun activity for children. The message given in the fairy tale is easy to accept and apply in daily life. Children are expected to internalize the value in fairy tales. Interactive fable tales are very interesting for kids. Animal character is a favorite for children, especially delivered interactively. Storytelling activities make the circumstance more alive and easier to deliver a message of fairy tale.

Children interpret themselves differently[8]. This will be the efficacy to present itself in the presence of others. There are children who are very enthusiastic in making friends, but others in otherwise, and they seem reluctant to be friends[9]. The self-concept is a figure of a person about himself that is formed through various experiences of environmental interaction[10]. The self-concept is expressed through the attitude of himself which is the actualization of the individual. Someone as organize that has the urge to development and ultimate lead to consciousness about his existence. Someone tends to reject change and misunderstand and then attempt to rectify information that is not consistent with their selfconcept.

The concept of self consists of positive and negative self-concept[3]. The positive self-concept means that a person is able to see himself / herself well. Negative self-concept means that one is unable to see herself well, so he tends to be shy. This self-concept comes from the family environment. The way parents treat the child can be known from the child's self-concept. Children do information absorption activities and imitate the model well. An effort to bring values in the 
formation of self-concept starts from their family environment. Positive self-concept of the child can be developed when there is assistance of his first environment.

Self-concept does not just happen. Of course there are some things that affect. Several things that affect the development of self-concept, i.e.:

1. The role of physical image

Failure and success to achieve the ideal standard of physical state greatly affects the formation of the individual's physical image. In general, the individual will strive to achieve ideal conditions for his physical state.

2. The role of sex

Women are often viewed as individuals who should stay home to take care of the household, so that he is less than optimal in developing his self-concept. Meanwhile, men have more freedom to develop potential.

3. The role of parental behavior The family is the first place to develop self-concept. Parental behavior becomes a reflection of their child.

4. The role of social factors

The structure, role, and social status of the individual become the foundation for others to look at themselves.

The factors that influence individual self-concept as follows[8]:

1. Parents

Parents are the earliest social contact for the child. Parents provide a constant flow of information about the child. Hope and judgment will continue until the child becomes an adult.

2. Peers

Acceptance and rejection of peer groups against individuals will affect the concept itself.

3. Society

The public's judgment and expectation of individuals can enter into individual self-concept so that it will have behavior in accordance with social behavior.

4. Learn

Learning is the result of individual learning. There are changes that are relatively permanent because of the training process

Fairy tale is a collective story of oral literature[11]. Furthermore, fairy tale is a story of people's prose that is not considered to be really happening. Fairy tales are told primarily for entertainment, although many also portray the truth, containing moral lessons, or even satire. While fable is a fairy tale that tells animals' behavior that have grooves and moral messages. Fable as a large group of fairy tales. This fable will be more interesting if presented interactively. Interactive is a matter of two-way communication/mutual action, active, and related, as well as provides reciprocity between one with another[12]. Both parties are active in performing one activity. Interactive storytelling activities will make the atmosphere livelier because it creates two-way communication.

Hypothesis is a temporary answer to be verified[13]. The hypothesis proposed in this study is that there are differences in self-concept of early childhood in interactive fable tale implementation.

\section{RESEARCH METHOD}

The variables used in this study are the Self-Concept of early childhood as the dependent variable and Interactive Fable Tale as the independent variable. The population in this study is early childhood education students in Gunungpati sub-district. Research sample is part of the population that must have the characteristics possessed by the population[13]. The sample in this research were students at Pertiwi 49 Kindergarten in Ngijo, Gunungpati. The sampling technique used was purposive sampling technique. The characteristics of the subjects in this study are students aged 4-6-year-olds who are recorded as active students.

The method of data collection used in this research to measure the positive self-concept of early childhood was Early Childhood Concept Scale. Self-concept scale of early childhood amounted to 31 items, with a validity level of 0.484-0.897 and reliability level of 0.908 , those were the scales compiled by researcher. The high and low self-concept of early childhood appears on the score obtained from the scale. The higher the score means the higher the self-concept of early childhood, and the lower the score obtained means the lower self-concept of early childhood.

The study was conducted at Pertiwi 49 Kindergarten in Ngijo, Gunungpati sub-district on September 15 to October 20, 2016. The Self Concept Scale was filled by the students with the help of researcher and research assistant. The teacher gave 12 interactive fables tales during the research. The method of data analysis that was used to find out the difference of early childhood self-concept in terms of interactive fable tale implementation was t-Test Independent Sample by using SPSS program (Statictical Package for Social Science) 16 for Windows.

\section{LITERATURE REVIEW AND DISCUSSION}

From the research data that has been analyzed, statistical description of research variables on Early Childhood SelfConcept Scale was obtained. The statistical description of research variables are as follows:

\begin{tabular}{|l|l|l|l|l|}
\hline No & $\begin{array}{l}\text { Early } \\
\text { Childhood } \\
\text { Self- } \\
\text { Concept }\end{array}$ & Mean & Min & Max \\
\hline 1. & $\begin{array}{l}\text { Experiment } \\
\text { Group }\end{array}$ & 91.62 & 60 & 112 \\
\hline 2. & $\begin{array}{l}\text { Control } \\
\text { Group }\end{array}$ & 77.12 & 55 & 110 \\
\hline
\end{tabular}

Furthermore, to find out the high and low scores of the subjects, a categorization on early childhood Self- Concept Scale was carried out. The categorization was based on an assumption that the subject score in the group is an estimate of the subject scores in the population and the subject scores in the population are normally distributed. The researchers used the following categorization, low $(\mathrm{x}=\mathrm{m}+-1 \mathrm{SD})$, medium ( $\mathrm{m}$ +-1 SD $<x=m+1$ SD), and high $(x>m+-1$ SD). The subject categories above are used to group the scores of the Self Concept Scale Variables as follows: 


\begin{tabular}{|l|l|l|l|l|}
\hline No & Score & Category & Freq & Percent \\
\hline 1. & $\mathrm{x} \leq 61$ & Low & 2 & $12.50 \%$ \\
\hline 2. & $\begin{array}{l}62<\mathrm{x} \\
\leq 93\end{array}$ & Medium & 5 & $31.25 \%$ \\
\hline 3. & $\mathrm{x} \geq 94$ & High & 9 & $56.25 \%$ \\
\hline
\end{tabular}

Based on the above categories, the early childhood selfconcept scores of the experimental group shows that 2 children $(12.50 \%)$ were in the low category, 5 children $(31.25 \%)$ were in medium category, and 9 children $(56.25 \%)$ were in the high category. When viewed as a whole, it can be concluded that the early childhood self-concept scores obtained by research subjects were in high category.

\begin{tabular}{|l|l|l|l|l|}
\hline No & Score & Category & Freq & Percent \\
\hline 1. & $\mathrm{x} \leq 61$ & Low & 5 & $31.25 \%$ \\
\hline 2. & $\begin{array}{l}62<\mathrm{x} \leq \\
93\end{array}$ & Medium & 8 & $50 \%$ \\
\hline 3. & $\mathrm{x} \geq 94$ & High & 3 & $18.75 \%$ \\
\hline
\end{tabular}

Based on the above categories, the early childhood selfconcept scores of control group shows that 5 children $(31.25 \%)$ were in the low category, 8 children $(50 \%)$ were in the medium category, and 3 children $(18.75 \%)$ were in the high category. When viewed as a whole, it can be concluded that the positive self-concept score of early childhood obtained by research subjects were in the medium category.

Data analysis was conducted to test the research hypothesis. This analysis was conducted with t-Test Independent Sample.

The result of hypothesis testing in this study is as follows:

\begin{tabular}{|l|l|c|c|c|}
\hline No & Variable & $\mathbf{t}$ & $\mathbf{P}$ & Note \\
\hline 1. & Early & 2.661 & 0.012 & there \\
& Childhood & & & was \\
& Positive & & & a \\
& Self- & & & diffe \\
& Concept & & & rence \\
\hline
\end{tabular}

The above hypothesis test resulted in a $\mathrm{t}$ value of 2.661 with $p<0.05$. Based on these results, it can be said that there are significant differences in self-concept of early childhood viewed from the interactive fable tale. The concept of early childhood in the experimental group is higher than the control group. The hypothesis in this study is accepted.

The results of this study are supported by Brooks who explained that in assessing or viewing himself, an individual can view positively or negatively[14]. If he views himself positively, he will be sure of his ability to deal with problems, feel equal with others, receive praise without shame, have different feelings and desires, and can improve his personality. If he views himself negatively, he will be sensitive to criticism, responsive to praise, tend to be hypercritical, feel disliked, and pessimistic about competition.

Fable tale is a simple fantasy story that can be used to convey moral teachings (educate) and also entertaining[15]. Fable tale method is one of the learning strategies for early childhood[16]. The tale will produce a certain meaning or value in children by using an event that is beyond reason or full of imagination as an example. Children can be given storytelling and story reading treatments[17]. In this study, research emphasis more on interactive fable tale. Children are very enthusiastic about stories that have high imagination and are given interactively. When abstractive thinking skills began to be developed; children are expected to distinguish between fantasy and reality. Both parties are active in performing one activity. There is a stimulus and response to clarify the message delivered. Storytellers provide feedback for children and children to be motivated to follow the storyline, to engage in it, and have an opportunity to come up with ideas. This interactive fable tale can be used by parents and teachers in the formation of self-concept of early childhood.

\section{CONCLUSION}

Based on the results of the study, it can be concluded that there are significant differences in self-concept of early childhood viewed from the interactive fable tale. The concept of early childhood in the experimental group is higher than the control group.

\section{References}

[1] P. R. Indonesia, "Undang-undang Republik Indonesia nomor 20 tahun 2003 tentang sistem pendidikan nasional," 2003.

[2] M. Samani, "Hariyanto.(2011) Konsep dan Model Pendidikan Karakter," Bandung: Remaja Rosda Karya.

[3] Desmita, Psikologi Perkembangan. Bandung: Rosdakarya, 2009.

[4] M. A. Mansur, "Pendidikan Anak Usia Dini dalam Islam," Yogyakarta: Pustaka Pelajar, 2005.

[5] C. M. Paik and W. B. Michael, "Further psychometric evaluation of the Japanese version of an academic self-concept scale," J. Psychol., vol. 136, no. 3, pp. 298-306, 2002.

[6] J. F. \& A. J. R. Calhoun, Psychology of Adjustment of Human Relationship. New York: McGraw Hill, Inc, 1990.

[7] Y. O. K. Pardede, "Konsep diri anak jalanan usia remaja," J. Ilm. Psikol., vol. 1, no. 2, 2011.

[8] S. Mulyadi, "Character Building, Tinjauan Berbagai Aspek Bagaimana Mendidik Anak Berkarakter." Yogyakarta: Tiara Wacana, 2008.

[9] G. S. Morrison, Early childhood education today. Merrill Publishing Company Columbus, Ohio, 1988.

[10] H. Agustiani, "Psikologi perkembangan pendekatan ekologi kaitannya dengan konsep diri dan penyesuaian diri pada remaja," Abstrak, 2006.

[11] J. Danandjaja, Folklor Indonesia: ilmu gosip, dongeng dan lainlain. Grafiti Pers, 1984.

[12] B. Warsita, "Teknologi pembelajaran landasan dan aplikasinya." Jakarta: Rineka Cipta, 2008.

[13] N. Martono, Metode Penelitian Kuantitatif: Analisis Isi dan Analisis Data Sekunder. Nanang Martono, 2010.

[14] J. Rakhmat, Psikologi Komunikasi. Bandung: PT Remaja Rosdakarya, 2003.

[15] R. C. Goddard, "Increase in assertiveness and actualization as a function of didactic training.," J. Couns. Psychol., vol. 28, no. 4, p. 
$279,1981$.

[16] Y. Nurfalah and A. Kusmiadi, "Sriwahyuningsi. 2008.'Strategi pembelajaran PAUD Melalui Metode Dongeng bagi Pendidik PAUD, "’ J. Ilm. VISI PTK-PNF, vol. 3, no. 2, pp. 198-203.
[17] R. Isbell, J. Sobol, L. Lindauer, and A. Lowrance, "The effects of storytelling and story reading on the oral language complexity and story comprehension of young children," Early Child. Educ. J., vol. 32, no. 3, pp. 157-163, 2004. 